\title{
Legal Aspect of Electronic Equipment Evidence in Cooperation with Over the Top Telecommunication Operator in Copyright Content Services on the Internet
}

\author{
Tasya Safiranita Ramli, Sherly Ayuna Putri \\ Faculty of Law \\ University of Padjadjaran \\ Bandung, Indonesia \\ tasya_safiranita@yahoo.com
}

\begin{abstract}
This study aims at exploring process of how the content protection that is available in OTT can be commercialized and the power of electronic proof of law in dispute settlement over the top (OTT). The approach used is juridical approach to normative and comparative legislation. Data are in the form of primary legal material comprising Book of the Civil Code, Law no. 19 Year 2016 on Information and Electronic Transactions, and Law number 28 of 2014 on Copyright; secondary legal material consists of literature and documents relating to research; related sources used are magazines, Big Indonesian Dictionary (KBBI), internet, legal journals, and research-related papers. Results show that OTT has disrupted the business of the telecommunication operators especially the voice and Short Message Service (SMS). OTT are also often associated with content abuse and copyright infringement. Loss of money by the operator is caused by an SMS or telephone service that is not used regularly and effectively; customers more often communicate through the data network. In addition, when viewed from other things it can be concluded that operators and OTT organizers must enhance digital content services to obtain appropriate legal protection and benefits in accordance with global development.
\end{abstract}

Keywords-electronical equipment; over the top; telecommunication operator; copyright content services; internet

\section{INTRODUCTION}

Over The Top (OTT) is a service provided through the operator's network and infrastructure but does not directly involve the operator [1]. This is a service that drives operators but excludes or involves operators. These services can be video, audio, sound, telecommunications, news, conferences, data centers, cloud services, network services, games, mobile messaging, and more. The presence of OTT requires telecommunication network providers and Internet Service providers (ISPs), called operators to increase the number of subscribers and profits gained to accelerate and increase sales rapidly on the rapid development of information technology to take advantage of on-line services in the form of e-Commerce [2]. Many ways that companies do in the use of information technology. Most companies use information technology as a competitor with other companies [1]. Government Regulation (PP) 82/2012 on Implementation of Electronic Transaction System and Transaction and Candidate of Ministry of Information and Communication [3]. 21/2013 on Cellular Content and FWA - should be upgraded with the aim of generating rules that accommodate the interests of every operator and regulator. In this case, in addition to being opposed by some circles within the country, OTT is an operator regulation. Therefore, in addition to improving regulation, a sustainable socialization of the need for regulation that can direct the OTT to share its benefits and responsibilities also needs to be done.

Based on Article 5 paragraph (1) of the Emergency Law no. 1 of 1951 in Indonesia, the applicable Civil Procedure Code is Herzien Inlandsch Reglement [HIR (Stb.1848 No. 16 jo Stb.1941 No. 44)] for Java and Madura; and Rechtreglement voor de Buitengewesten (RBg) (Stb.1927 No. 227) for areas outside Java and Madura; Rv. (Stb.1847 No. 52 jo Stb.1849 No. 63) is by virtue of other civil law, resulting in a legal pluralism. HIR and RBg are part of Dutch East Indies law as it is a product of the Dutch colonial government that is still in force today [4]. The Indonesian nation since its independence has not yet established a new civil procedure law as an amendment to the current civil law as evidenced by the Civil Procedure Code is still in the process of preparation. Along with developments in the community characterized by the development of information technology and telecommunications, there is also a variety of evidence in civil law that has been set in the rules of the civil event (HIR/RBg). The decision of the Supreme Court of April 14, 1976 $\mathrm{K} / \mathrm{Sip} / 1974$, states that it may be admitted as evidence accompanied by a statement or by any means may be legally demonstrated that it is in accordance with the original [5]. At the time of submission of the proof, all letters either in the form of deed (authentic and under hand) or acts of action are used as written evidence in the proceedings in court. 
In court, the facts of proof must be the same as the original which was then ratified by the judge as evidence that it was in accordance with the original and then initialed on the fact of the proof of the letter. Photographs and sound or picture recordings (ongoing including CCTV recordings), based on the literature cannot be used as evidence so they cannot prove what really happened. But in its current development, with advances in technology in the field of information and telecommunications, the recording of sound or image can be known by using certain techniques. Prints from fax machines (known as faxes) are widely used in remote short-term correspondence, as well as microfilm or microfiche used to store data, which can be considered written proof [5].

Based on the above statement, in this paper, problems to be analyzed are content protection that is available in OTT can be commercialized and how the power of electronic proof of law in dispute settlement Over the Top (OTT) looks like.

\section{METHOD}

Normative jurisdiction is a type of research by explaining the provisions in applicable laws and regulations. The comparative juridical definition which is the study is based on the comparative law which in developing countries is used to compare national and international legal instruments in the field of legal protection of information, documents and electronic transactions.

Research specifications include descriptive analytic descriptive and descriptive qualitative research design. Descriptive analytical describes and provides an explanation of an event that is studied and analyzed based on data obtained under the theory of applicable provisions that can provide an overall explanation both from the field of copyright law and technology so that written conclusions can be obtained. Qualitative descriptive applied with the form of research with case study approach. This study focuses intensively on a particular object that studies it as a case. Case study data can be obtained from all relevant parties, in other words data in this study were collected from various sources.

This research is more emphasized on bibliographic data analysis, but to complete the field research, library research done, so the research is done in two stages, namely field research and library research that was conducted to collect secondary data. This is done to find matters relating to the issues discussed in this study. Furthermore, there are two types of legal materials used in this study, namely: (1) primary legal materials, including the Book of the Civil Code, Law no. 19 of 2016 on Information and Electronic Transactions, and Law number 28 of 2014 concerning Copyright; (2) the secondary legal material consists of literature and documents relating to research; and other legal sources used are magazines, Big Indonesian Dictionary (KBBI), internet data, legal journals, and research-related papers.

\section{RESULT AND DISCUSSION}

Commercial Content Protection in Commercial Media of OTT Information technology and telecommunications can be in various fields such as education, business, government and social. The rapid development of Science and Technology (IPTEK) has become a reality in everyday life even the demands of society that cannot be negotiable. The ultimate goal of science and technology development is a change in the future of human life that is better, easier, cheaper, faster and safer. The development of science and technology, especially information technology such as the internet, strongly supports everyone to achieve their goals in a short time, both legal and illegal to gain profit by "cutting the compass".

The adverse effects of this "cyberspace" development cannot be avoided. In terms of copyright it can be said that Software protection in cyberspace exists on the rules of software copyright can be found in several international conventions, one of which is the reference Berne Convention for the Protection of Literary and Artistic Works 1886 ratified by President Degree No. 18 of 1997, is the oldest convention on copyright. In this convention is not set about software, but because software is a literary works. In Article 2 Paragraph (1) Bern convention explained that software is literary works that must be protected. In addition there is also a set of software copyright settings in the Inside TRIPs rules on software copyright arranged in Article 10 which explains that computer programs should be protected as literary works. In TRIPs, the notion of computer program is described in Article 10 Paragraph (1), namely: Article 10 Computer Programs and Compilations of Data (1) Computer programs, whether in source or object code, shall be protected as literary works under the Berne Convention (1971). It makes that in the Settings in the Copyright Act Number 28 of 2014. 1. Article 1 point 9: A computer program is a set of instructions expressed in the form of a language, code, scheme, or in any form intended for the computer to perform certain functions or to achieve certain results.

Based on the fact, OTT is a service with content in the form of data, information or multimedia that runs through internet network. It can be said also OTT service is "ride" because it is operating on the internet network owned by a telecommunications operator.

In this case copyright has a special role to protect on the internet media, but in fact some examples of companies in the service OTT is Facebook, Twitter, Youtube, Viber, and others. OTT service companies such as WhatsApp and others generally do not have any form of official cooperation with telecommunication providers. Based on this, communication technology is demanded and leads to efficiency boundaries of territory unimpeded by state borders, without time constraints. One technology that successfully answered the need is the internet. The Power of Electronic Proof Laws in Over the top (OTT) Dispute Settlement Through the establishment of actual material law in Indonesia there have been several actions that led to the use and acknowledgment of electronic documents as legal evidence, for example by the recognition of online trading in stock exchanges and the arrangement of micro films and electronic means as media storage of corporate documents regulated in the Law -No. 8 Year 1997 About Company Document. The arrangement of the Company Document to reach electronic evidence, as it has given the possibility to the company documents that have been assigned as authentic written evidence for the storage in the form of microfilm. 
Furthermore, the documents stored in electronic form (paperless) can be used as legal evidence in case of a dispute to the court. According to Article 1 number 3 of Law no. In electronic information, electronic information is one or a set of electronic data, including but not limited to writing, sound or images, maps, designs, photographs or the like, letters, signs, numbers, access codes, symbols or perforations. That has been processed so that it has meaning. Limitations on Electronic Documents. According to Article 1 number 14 is any electronic information created, forwarded, transmitted, received, or stored in the form of analog, digital, electromagnetic, optical or the like; which may be viewed, displayed and/or heard through a computer or electronic system, including but not limited to writing, sound or images, maps, designs, photographs or the like, letters, signs, numbers, access codes, symbols.

\section{CONCLUSION}

Operators loose that money because SMS or telephone service is less used, customers more often communicate via data network. When it is viewed from other things it can be concluded that operators and OTT organizers should to improve services of digital content to get the protection and the benefits are appropriate when viewed from the development of this era. The electronic information is also recognized by the provision that the electronic are extensions of valid evidence in accordance with applicable law in Indonesia, as to the requirement that electronic information may be declared valid when using an electronic system according to the rules of prevailing laws.

\section{ACKNOWLEDGEMENT}

Operator and OTT should be synergize because without the content then the data is not needed anymore due to the rise of people who have switched from the era of SMS and who now use the social media services. The boomerang that the existence of OTT become enemy for the operator. Because in addition to not paying, the application is channeled messaging service that a lot of network capacity drain and resulted in lower quality of service. The validity of electronic documents as evidence in court does not yet have legal force against the state that has not yet been regulated regarding electronic information and transactions. This will result in legal uncertainty against the party performing the transfer of information and electronic transactions if the transactions are conducted between countries.

\section{REFERENCES}

[1] Tymutz, Information Technology for Competitive Advantage in Company Operations. Berne Convention for the Protection of Literary and Artistic Works 1886, 2009.

[2] Siregar, Strategy Improving Business Competition Company with ECommerce Implementation. 2010.

[3] S. Mertokusumo, Civil Procedure Indonesia. Liberty: Yogyakarta. Lindsey's Team, Intellectual Property Rights An Introduction. Bandung: PT Alumni, 2006.

[4] E. Makarim, Introduction to Telematics Law a Compilation of Study. Jakarta: PT. Raja Grafindo Persada, 2005.

[5] E. L. Fakhriah, Electronic Evidence in Civil Proof System. Bandung: PT Alumni, 2011. 